Article

\title{
Combination of River Bank Filtration and Solar-driven Electro-Chlorination Assuring Safe Drinking Water Supply for River Bound Communities in India
}

\author{
Philipp Otter ${ }^{1, *(1)}$, Pradyut Malakar ${ }^{2}$, Cornelius Sandhu ${ }^{3}\left(\mathbb{C}\right.$, Thomas Grischek $^{3} \mathbb{C}^{-}$, \\ Sudhir Kumar Sharma ${ }^{4}$, Prakash Chandra Kimothi ${ }^{4}$, Gabriele Nüske ${ }^{5}$, Martin Wagner ${ }^{5}$, \\ Alexander Goldmaier ${ }^{1}$ and Florian Benz ${ }^{1}$ \\ 1 AUTARCON GmbH, D-34117 Kassel, Germany; goldmaier@autarcon.com (A.G.); benz@autarcon.com (F.B.) \\ 2 International Centre for Ecological Engineering, University of Kalyani, Kalyani, West Bengal 741235, India; \\ pradyutmalakar2@gmail.com \\ 3 Division of Water Sciences, University of Applied Sciences Dresden, D-01069 Dresden, Germany; \\ cornelius.sandhu@htw-dresden.de (C.S.); thomas.grischek@htw-dresden.de (T.G.) \\ 4 Uttarakhand State Water Supply and Sewerage Organization, Uttarakhand Jal Sansthan (UJS), \\ Dehradun 263139, India; sudhirksharma10@yahoo.com (S.K.S.); pckimothi@gmail.com (P.C.K.) \\ 5 Technologiezentrum Wasser (TZW) Karlsruhe, D-01326 Dresden, Germany; \\ gabriele.nueske@tzw.de (G.N.); martin.wagner@tzw.de (M.W.) \\ * Correspondence: otter@autarcon.com; Tel.: +49-561-5061 86892
}

Received: 30 October 2018; Accepted: 2 January 2019; Published: 11 January 2019

\begin{abstract}
The supply of safe drinking water in rural developing areas is still a matter of concern, especially if surface water, shallow wells, and wells with non-watertight headworks are sources for drinking water. Continuously changing raw water conditions, flood and extreme rainfall events, anthropogenic pollution, and lacking electricity supply in developing regions require new and adapted solutions to treat and render water safe for distribution. This paper presents the findings of a pilot test conducted in Uttarakhand, India, where a river bank filtration (RBF) well was combined with a solar-driven and online-monitored electro-chlorination system, treating fecal-contaminated Ganga River water. While the RBF well provided nearly turbidity- and pathogen-free water as well as buffered fluctuations in source water qualities, the electro-chlorination system provided disinfection based on the inline conversion of chloride to hypochlorous acid. The conducted sampling campaigns provided complete disinfection $(>6.7 \mathrm{log})$ and the adequate supply of residual disinfectant $(0.27 \pm 0.17 \mathrm{mg} / \mathrm{L})$. The system could be further optimized to local conditions and allows the supply of microbial-safe water for river bound communities, even during monsoon periods and under the low natural chloride regimes typical for this region.
\end{abstract}

Keywords: electro-chlorination; smart villages; disinfection; river bank filtration; rural water supply, online monitoring

\section{Introduction}

The Millennium Development Goal to halve the number of people without access to improved water sources was achieved in 2015-five years ahead of schedule. By that, 2.6 billion people gained access to improved water sources. However, there is substantial evidence that improved sources of drinking water, including piped water, can contain fecal contamination and studies estimate that 1.8-2.0 billion people drink such water [1-4]. Every year 502,000 deaths are caused by diarrheal diseases that can be attributed to the consumption of unsafe water [4]. Especially rural communities are prone 
to having no access to safe drinking water. Lack of infrastructure, technical expertise, user compliance, as well as the lack of supply of chemicals and electricity have been identified as reasons for the failure of rural water treatment and supply systems [5]. Point-of-use (PoU) treatment approaches are often considered as alternatives and have shown to reduce the risk of diarrheal infections by $40 \%$ [6]. However, the effectiveness of PoU disinfection (including chlorination) depends highly on the comprehension and willingness of the households to apply the treatment systems correctly, especially under varying source water conditions [6-8]. Turbidity impedes the application of chlorine and other disinfection methods. In that case additional filtration is required, increasing the complexity and costs for PoU treatment. In the end, the responsibility for safe water supply is passed on to the end user and the educational and motivational efforts required for establishing a reliable application of PoU may not pay off.

The here presented combination of river bank filtration (RBF) and solar-driven electro-chlorination $\left(\mathrm{ECl}_{2}\right)$ could be a feasible option for the decentralized treatment of surface water in river bound communities. Reported data show that RBF can effectively remove many major water pollutants and micro-pollutants, including particulates, colloids, algae, pathogens, organic as well as inorganic compounds, microcystins, and heavy metals $[9,10]$. Log reductions for total coliforms of 5.5-6.1 and for bacteriophages of $>4.4$ were reported by [11,12]. Total organic carbon (TOC) removal rates of $60 \%$ are possible [13]. Whereas conventional treatment methods, like coagulation-filtration, can reduce the disinfection by-product (DBP) formation potential by $25 \%$ [13], the reduction can reach $50 \%-80 \%$ using RBF, without any waste sludge produced. Furthermore, RBF is able to attenuate temperature peaks and can provide protection against shock loads. Although inorganic contamination is less likely found in bank filtrate [9], oxygen may be depleted during the passage of the water through the bank. Under anoxic conditions, iron, manganese, and even arsenic can re-mobilize and enter bank filtration wells [14]. During the planning process of RBF abstraction sites such aspects have to be considered and recommendations for safe management of RBF sites in India were published [15].

In the US, RBF has received log-credits for pathogen removal and is mainly used for the removal of suspended solids. The sites are often designed with shorter travel times compared to Europe, where RBF has been widely applied for more than 130 years to produce drinking water along the Rhine, Elbe, Danube, and Seine rivers. Furthermore, in developing regions, the interest in RBF is increasing and the feasibility of its application has been evaluated under different hydrological and hydrogeological conditions (e.g., in India [16], Egypt [17], and Thailand [18]).

However, the application of RBF wells alone does not assure long-term microbial-safe water. Despite the cited removal rates, monitoring campaigns and risk assessment studies have repeatedly shown the presence of total coliforms and Escherichia coli (E. coli) in RBF wells, even at greater distances (48-190 m) to the river bank [12,19]. In Haridwar (northern India), where the pilot site for this project is located, such incidents could be related to the seepage of fecal contamination in the direct vicinity of the wells [19]. Further, recontamination may occur also during distribution and storage, justifying further disinfection. Here, chlorine, in contrast to, for example, UV-treatment or ultrafiltration (UF), has a long proven record of rendering water safe during storage and distribution-if handled correctly $[20,21]$. In rural communities; however, chlorination systems have failed for the same reasons as stated above, as they require constant availability of chemicals, skilled personnel capable in evaluating the chlorine demand of the water, and strict compliance with existing guidelines. Furthermore, the application of chlorine compounds is challenged by the formation of DBPs if applied in unfavorable source water conditions. Even though the risks for microbial contamination usually exceed the adverse side effects of chlorination [22,23], guideline values for chlorine dose and inorganic and organic DBP concentrations exist (Table 1).

The inline-electrolytic production of chlorine $\left(\mathrm{ECl}_{2}\right)$ could pose a feasible alternative towards the dosing of chlorine. Here, gaseous chlorine is produced directly at the anode of an electrolytic cell from the chloride dissolved in the water that is to be treated (Equation (1)). The chlorine gas rapidly dissociates in water to hypochlorous acid, being chemically the same oxidizing agent as in 
conventional chlorine dosing systems (Equation (2)). The chlorine gas production is accompanied by a decrease of $\mathrm{pH}$ (Equation (3)) and the evolution of hydrogen gas at the cathode (Equation (4)) [24].

Table 1. Selected guideline values concerning the chlorination of drinking water.

\begin{tabular}{ccccc}
\hline Parameter & Germany & EU & WHO & India IS 10500 \\
\hline Free Available Chlorine $(\mathrm{FAC})[\mathrm{mg} / \mathrm{L}]$ & $1.2^{\mathrm{a}} / 0.1-0.3^{\mathrm{b}}$ & & $>0.5$ & $0.2 / 1.0$ \\
Bromate $[\mu \mathrm{g} / \mathrm{L}]$ & 10 & 10 & 10 & - \\
Chlorate $[\mu \mathrm{g} / \mathrm{L}]$ & $200^{\mathrm{d}}$ & $250^{\mathrm{e}}$ & 700 & - \\
Chlorite $[\mu \mathrm{g} / \mathrm{L}]$ & 200 & $250^{\mathrm{e}}$ & 700 & - \\
Trihalomethanes $(\mathrm{THM})[\mu \mathrm{g} / \mathrm{L}]$ & $10^{\mathrm{b}} / 50^{\mathrm{c}}$ & 100 & $60-300$ & - \\
Bromoform $[\mu \mathrm{g} / \mathrm{L}]$ & & & & 100 \\
Dibromochloromethane $[\mu \mathrm{g} / \mathrm{L}]$ & & & 60 \\
Bromodichloromethane $[\mu \mathrm{g} / \mathrm{L}]$ & & & 200 \\
Chloroform $[\mu \mathrm{g} / \mathrm{L}]$ & & & \\
\hline
\end{tabular}

${ }^{a}$ During treatment. ${ }^{b}$ At the end of treatment. ${ }^{c}$ Point of use. ${ }^{d}$ Valid by the time of pilot test; was reduced to $70 \mu \mathrm{g} / \mathrm{L}$ in December 2017. ${ }^{\mathrm{e}}$ As currently proposed [25].

Anodic reaction chlorine:

Dissociation of chlorine gas in water:

Anodic reaction oxygen:

Cathodic reaction:

$$
\begin{aligned}
& 2 \mathrm{Cl}^{-} \leftrightarrow \mathrm{Cl}_{2}+2 \mathrm{e}^{-} \\
& \mathrm{Cl}_{2}+2 \mathrm{H}_{2} \mathrm{O} \leftrightarrow \mathrm{HClO}+\mathrm{Cl}^{-}+\mathrm{H}_{3} \mathrm{O}^{+} \\
& 2 \mathrm{H}_{2} \mathrm{O} \leftrightarrow \mathrm{O}_{2}+4 \mathrm{H}^{+}+4 \mathrm{e}^{-} \\
& 2 \mathrm{H}_{3} \mathrm{O}^{+}+2 \mathrm{e}^{-} \leftrightarrow \mathrm{H}_{2}+2 \mathrm{H}_{2} \mathrm{O}
\end{aligned}
$$

To power this process a DC voltage is applied to dimension stable (DSA) titanium electrodes coated with platinum group metals. Studies have shown that coatings comprising iridium and or ruthenium oxides (MOX electrodes) produce consistently higher chlorine output compared to platinum coatings $[26,27]$. In comparison to the manifold in literature-described boron-doped diamond (BDD) electrodes, MOX electrodes are less prone to produce DBPs, especially considering chlorate and perchlorate $[28,29]$.

To control the production of chlorine, fundamental knowledge about the functional interrelationship between chloride concentration, current, current density, electrode material, temperature, and source water quality is required and has become available only very recently [30]. Systematical evaluation on the effectiveness of the produced disinfecting agents and the potential formation of disinfection by-products (DBP) has shown that the application of inline-electrolysis is comparable to the application of hypochlorous acid $[24,27,28,30]$. However, uncertainty towards the long-term operability, the effectiveness under very low chloride regimes, and elevated hardness levels persists $[27,28]$.

For the first time a combination of RBF and solar-driven inline-electrolysis was tested in a long term trial in northern India. The intention of this combination between natural and engineered solutions (cNES) was to merge the above-mentioned benefits of RBF for surface water treatment with the benefits of residual chlorination, eliminating the above-mentioned drawbacks of chemical dosing. The here presented data summarize the findings of two intensive sampling periods conducted within a two and a half year pilot trial. The main target was to evaluate the pathogen removal and residual disinfection capacity. The first eight-month sampling campaign lasted from March-November and included one monsoon season (July-September). The second sampling campaign lasted for two weeks and was conducted after system optimization. Further, the formation of DBPs and energy efficiency of this water treatment approach was evaluated and suggestions for long-term operation and maintenance requirements were derived. 


\section{Materials and Methods}

\subsection{Bank Filtration at the Haridwar Site}

The test was conducted in Haridwar, India, where $68 \%$ of the drinking water supply for the city is produced by RBF [15]. The used large diameter well (IW \#18) is situated on Pant Dweep Island, located between the Upper Ganga Canal and the Ganga River (Figure 1). The distance to the nearest canal bank is $115 \mathrm{~m}$. The siting of the well (IW \#18) on an island and the significant natural gradient of the water table result in a high proportion of bank filtrate in the abstracted water. The water table in the well varies between 6 and $8.5 \mathrm{~m}$ bgl.

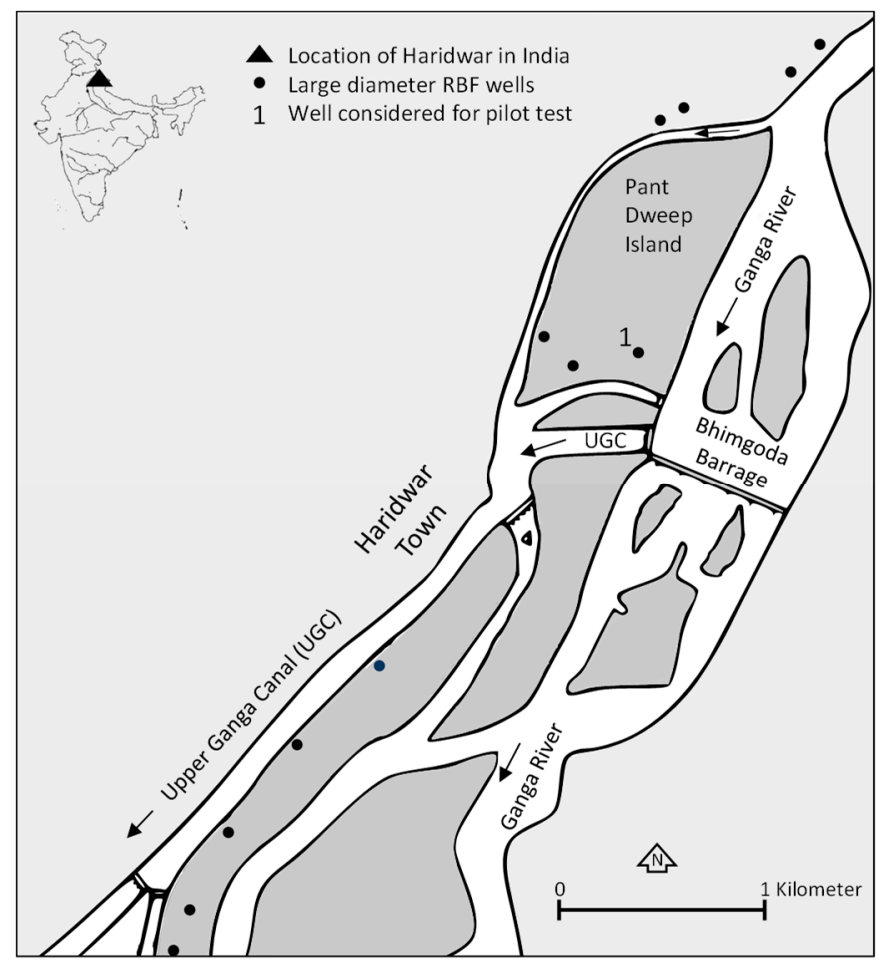

Figure 1. Location of the large diameter well on Pant Dweep Island at Haridwar (after [12]).

Studies conducted at two monitoring wells, starting in 2005, revealed that the bank filtrate contains dissolved organic carbon (DOC) of less than $1 \mathrm{mg} / \mathrm{L}$ under aerobic conditions. Trace metals were found to be below the Indian Standard IS 10500 (1991) limit [12]. The abstracted water from all the RBF wells in Haridwar only require disinfection and thus are well suited for the conduction of the pilot test.

\subsection{Inline Electrolysis}

The inline electrolytic chlorination unit tested during this trial was originally designed for surface water filtration and disinfection. The $\mathrm{ECl}_{2}$ cell stack in this pilot had a total surface area of $600 \mathrm{~cm}^{2}$ and was operated with a maximum current of $5 \mathrm{~A}$, which resulted in a maximum current density of $8.5 \mathrm{~mA} / \mathrm{cm}^{2}$. The cells polarity was inverted every $60 \mathrm{~min}$ to remove potentially-forming calcareous deposits from the cathode. At very low chloride concentrations the chlorine production efficiency may not be sufficient to meet the chlorine demand of the water. In that case, the station automatically reduces its flow rate. This works well; however, it also reduces the treatment capacity of the station and thus the economic feasibility. In prior studies conducted with good source water conditions, $10 \mathrm{mg} / \mathrm{L}$ of natural chloride in the water has been identified as the minimum chloride concentration for flow rates up to $100 \mathrm{~L} / \mathrm{h}$ [26]. In the here described pilot test an average treatment capacity of $200 \mathrm{~L} / \mathrm{h}$ was anticipated and the natural chloride concentration of the bank filtrate was only $14 \pm 2 \mathrm{mg} / \mathrm{L}$. Due to 
that, the pilot station was equipped with an automated $\mathrm{NaCl}$ dosing system, which would start to dose $\mathrm{NaCl}$ solution into the feed water tank under the following conditions:

(a) $\mathrm{ORP}_{\text {drinking water tank }}<\mathrm{ORP}_{\text {target }}$ and

(b) Voltage $_{\mathrm{ECl} 2 \text { cell }} /$ Current $_{\mathrm{ECl} 2 \text { cell }} \geq 3$.

If these requirements were met the system would start dosing $\mathrm{NaCl}$ solution until either the ratio of 3 or the target oxidation reduction potential (ORP) was reached. At a constant cell voltage of $12 \mathrm{~V}$, a current of $4 \mathrm{~A}$ would be required to stop dosing and the water would then contain a chloride concentration of about $50 \mathrm{mg} / \mathrm{L}$. As target ORP a value of $720 \mathrm{mV}$ in the first and $700 \mathrm{mV}$ in the second pilot phase were set. With that a Free Available Chlorine (FAC) conentration of $0.2-0.5 \mathrm{mg} / \mathrm{L}$ was anticipated.

For the first trial, the treatment system was equipped with a 9-inch pressurized vessel containing Activated Filtration Media (AFM) to remove potential turbidity still present in the bank filtrate. The filter was automatically backwashed after three days, independent of the quantity of water that had passed through the filter. During the second short test phase, a second filter was installed after the $\mathrm{ECl}_{2}$ cell to remove calcareous deposits that were released from the cathode after polarity inversion and had slightly increased the turbidity in the final storage water tank.

A submersible pump lifted the bank filtrate into a $2 \mathrm{~m}^{3}$ feed tank. The water was then pumped by an internal system pump through Filter 1 and the electrolytic reactor and into a $1 \mathrm{~m}^{3}$ final water storage tank (Figure 2). The chlorine production capacity of the cell was increased by adjusting $\mathrm{ECl}_{2}$ cell current and the flow rate, which was measured with a GEMÜ 850 flow sensor.

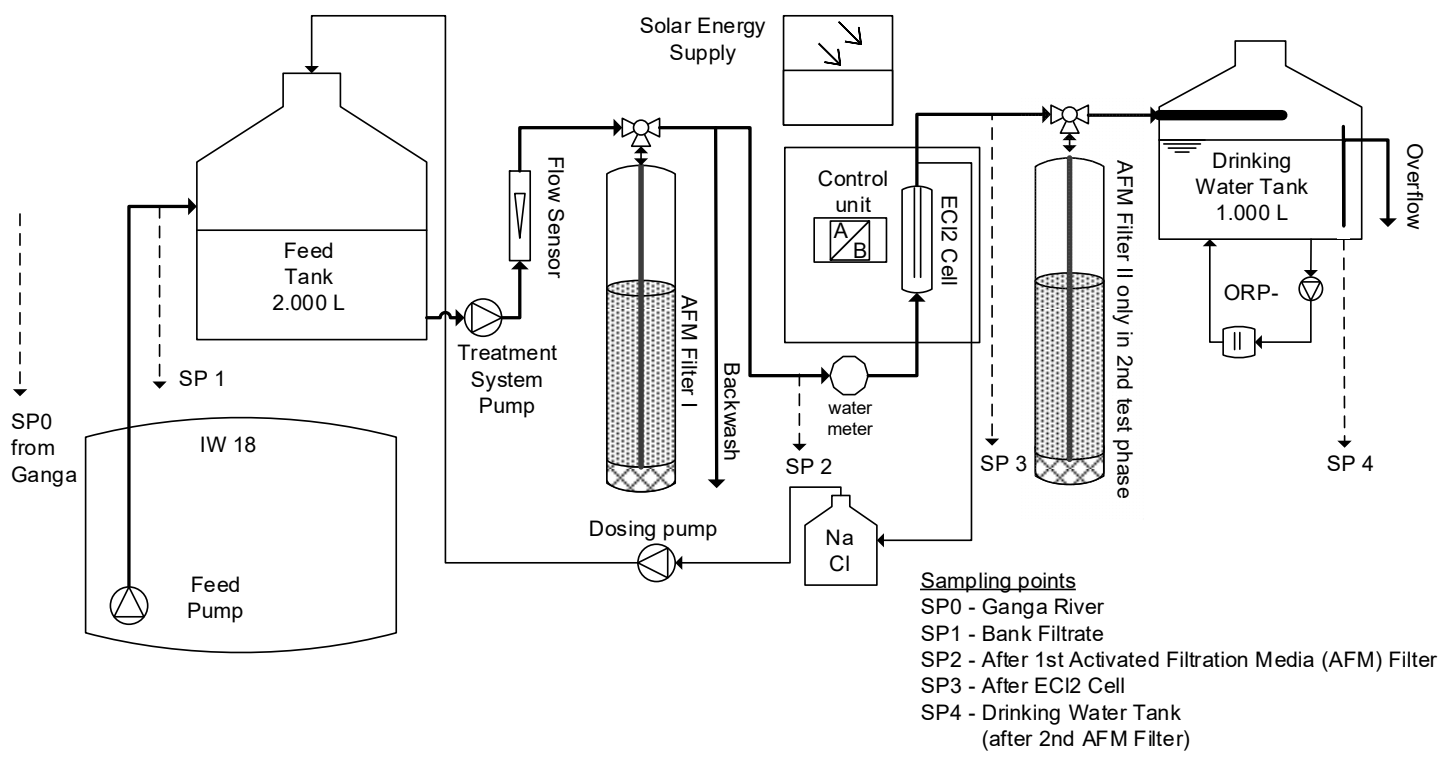

Figure 2. Pilot system setting at well IW \#18, Haridwar.

\subsection{Sampling, Water Analysis, and Monitoring}

For water quality analysis, random samples were taken one to two times per week at five sampling points (SP0 Ganga River, SP1 bank filtrate, SP2 after AFM filtration, SP3 directly after inline electrolysis, SP4 in final drinking water storage water tank) (Figure 2). Electric conductivity (Hach CDC 101), dissolved oxygen (LDO 101), and pH (Hach PHC 101) were measured with a Hach Multimeter HQ40d (Düsseldorf, Germany). The ORP in SP1 (bank filtrate) and SP4 (drinking water) was measured directly with the pilot system using a Jumo tecLine Rd electrode (Fulda, Germany). For parameters shown in Table 2, an Aqualytic AL410 (Dortmund, Germany) handheld photometer was used. Analysis of immediate parameters and parameters in Table 2 were done on site. 
Table 2. Parameters and methods used for analysis with the AL410 photometer.

\begin{tabular}{llll}
\hline Parameter & Wavelength in $\mathbf{n m}$ & Method & Range \\
\hline Free Available Chlorine (FAC) & 530 & 100: DPD1 & $0.01-6$ \\
Total Chlorine & 530 & 100: DPD3 & $0.01-6$ \\
$\mathrm{NH}_{4}-\mathrm{N}$ in mg/L & 610 & 60: Indophenole & $0.02-1$ \\
$\mathrm{Cl}^{-}$in mg/L * & 530 & 90: Silver nitrate/turbidity & $0.5-25$ \\
Total Hardness in mg/L CaCO & 560 & 200: Metalphthalein & $2-50$ \\
\hline \multicolumn{2}{c}{${ }^{*}$ Chloride was additionally determined through titration based on APHA Method 4500-Cl- ${ }^{-}}$.
\end{tabular}

Pathogens, DBPs, and UV-absorption (UVA, wavelength $254 \mathrm{~nm}$ ) were analyzed in laboratories of Uttarakhand Jal Sansthan, the state water supply agency, or at TZW Dresden, Germany. Total coliforms and E. coli were monitored following DIN EN ISO 9308-2 using Colilert $\odot$ Quanti-Tray@ from IDEXX Laboratories, Inc. (Westbrook, CT, USA) with a $24 \mathrm{~h}$ incubation time. Samples containing chlorine were quenched using thiosulfate directly after sampling. Turbidity was measured in Nephelometric Turbidity Units (NTU) with a Turb 430 IR/T from WTW (Weilheim, Germany) following DIN EN ISO 7027 (Nephelometric Turbidity Unit). Operational parameters, such as electrolytic cell current, flow rate, power consumption of the pump, and filtration intervals, were monitored using a system integrated Supervisory Control and Data Acquisition (SCADA) system. The chlorine demand was determined based on [31] by determining the difference between FAC directly after chlorine production and after $30 \mathrm{~min}$ at SP3. Combined chlorine mainly caused by reaction with nitrogen compounds was determined as the difference between total chlorine and FAC at SP3 and SP4. UVA-254 was determined using a Lambda 25 PerkinElmer (Waltham, MA, USA) following DIN 38-404-C3. Inorganic DBP analysis (chlorate, chlorite, perchlorate, bromate) for the first trial period was done for a duration of four months following DIN EN ISO 10304-4 and TZW lab method, using an ICS 3000 by Thermo Fischer Scientific (Waltham, MA, USA) having a detection limit of $1 \mu \mathrm{g} / \mathrm{L}$. In the second short time trial, random samples were analyzed for Trihalomethanes (THMs) following DIN EN ISO 10301, using a 7890A GC/MS by Agilent Technologies (Santa Clara, CA, USA) with a detection limit of $0.1 \mu \mathrm{g} / \mathrm{L}$. DBP samples were transported to Germany. In order to reduce the number of samples in the first test phase, all samples of a sampling week (generally 2-3) were mixed, conserved, and then analyzed.

The specific energy demand per $\mathrm{m}^{3}$ of drinking water produced was calculated using SCADA data, summarizing the produced water and the power required for running the system. Here, the energy consumption of the pump lifting the bank filtrate, the pump pushing the water through the system, the electrolytic cell, and the power supply for the control and online monitoring units, was evaluated.

\subsection{Solar Energy Supply System}

Due to the potentially non-existing or unreliable electricity supply in future target regions of the here tested system, the supply with solar photovoltaic (PV) electricity only was evaluated. Planned or unplanned electricity shortages are permissible when $\mathrm{ECl}_{2}$ is applied, as the residual disinfectant assures safe water conditions during water storage. This is one main advantage compared to alternative disinfection processes based on, for example, UV radiation, whereby power supply has to be always guaranteed if water is supplied for $24 \mathrm{~h}$ per day. For sizing an adequate solar PV system, different combinations of the photovoltaic (PV) generator size and battery capacities were subject to a sensitivity analysis using Homer [32]. The established model hereby considered the technical parameters given in Table 3.

Figure 3a shows the clearness indicies and the global horizontal radiation values at the pilot site. The acutal solar PV generator installed in Haridwar is shown in Figure 3b.

Following the below presented results of the sensitivity analysis, the solar energy supply system installed at the pilot site comprised a $900 \mathrm{Wp} \mathrm{PV}$ generator and $2 \times 96 \mathrm{Ah}$ (C10) valve-regluated lead-acid (VRLA solar batteries). 
Table 3. Technical parameters for sensitive analysis conducted with Homer.

\begin{tabular}{|c|c|}
\hline Parameter & Value \\
\hline \multicolumn{2}{|l|}{ Solar radiation } \\
\hline Average monthly clearness indices for Haridwar in $\mathrm{kWh} / \mathrm{m}^{2} \mathrm{~d}$ * & See Figure 1 \\
\hline \multicolumn{2}{|l|}{ Photovoltaic (PV) panel } \\
\hline Slope, Azimuth & $20,0^{\circ}$ West of South \\
\hline Nominal operational temperature and temperature coefficient & $47^{\circ} \mathrm{C},-0.5 \% /{ }^{\circ} \mathrm{C}$ \\
\hline PV module Efficiency & $14 \%$ \\
\hline PV generator size considered for sensitivity analysis (24 V) & $0.6,0.8,0.9$, and $1.0 \mathrm{~kW}$ \\
\hline \multicolumn{2}{|l|}{ Batteries } \\
\hline Minimum state of charge (SOC) & $40 \%$ \\
\hline Battery capacity (C10) considered for sensitivity analysis (24 V) & $50,96,144 \mathrm{Ah}$ \\
\hline \multicolumn{2}{|l|}{ Load } \\
\hline Load, day-to-day variability, time-step-to-time-step variability & $70 \mathrm{~W}, 5 \%, 5 \%$ \\
\hline Operational duration ** $*$ * & $22 \mathrm{~h}$ per day \\
\hline \multicolumn{2}{|l|}{ Constraints } \\
\hline Maximum annual capacity shortage, operational reserve & $1 \%(88 \mathrm{~h} / \mathrm{a}), 10 \%$ hourly load \\
\hline
\end{tabular}

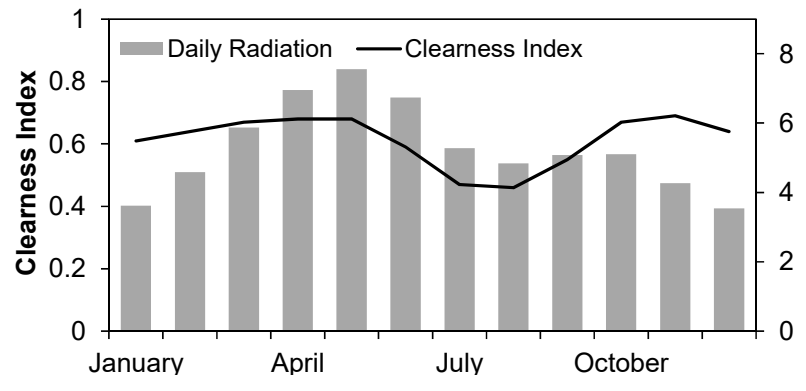

(a)

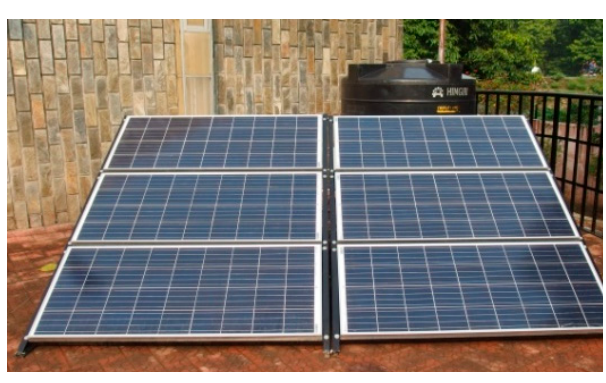

(b)

Figure 3. Clearness indices and monthly global horizontal radiation values (a); and the installed solar system (b).

\section{Results and Discussion}

\subsection{System Operation Haridwar}

The evaluated trial phase lasted 244 days, including downtimes of in total 24 days. During most of the time the station operated without technical problems and allowed continuous sampling. Reasons for downtimes were, for example, low water levels in the well, infrequent cleaning of PV modules with subsequent power failure, pump failure. Despite the polarity inversion, the operation in Haridwar was challenged from time-to-time by sudden growth of calcareous deposits on the electrolytic cell following elevated levels of hardness in the source water. Those are believed to have initiated crystallization at the cell allowing fast build-up of deposits. Deposits needed to be manually removed from the cell using acid.

\subsection{Water Quality Parameters Haridwar}

Major water quality parameters of the Ganga River water and bank filtrate of the first sampling period are summarized in Table 4. 
Table 4. Water quality of the Ganga River water and bank filtrate.

\begin{tabular}{|c|c|c|c|c|}
\hline Parameter & Mean \pm SD Ganga River & Mean \pm SD Bank Filtrate & n Ganga & n Bank Filtrate \\
\hline \multicolumn{5}{|l|}{ Pathogens } \\
\hline Total coliforms (MPN/100 mL) & $1.07 \times 10^{6} \pm 1.89 \times 10^{6}$ & $8.87 \times 10^{1} \pm 1.20 \times 10^{2}$ & 10 & 30 \\
\hline E. coli $(\mathrm{MPN} / 100 \mathrm{~mL})$ & $2.34 \times 10^{4} \pm 6.34 \times 10^{4}$ & $1.09 \times 10^{1} \pm 1.79 \times 10^{1}$ & 13 & 26 \\
\hline \multicolumn{5}{|l|}{ Chemical parameters } \\
\hline Hardness (mg/L) & $92 \pm 39$ & $207 \pm 40$ & 19 & 41 \\
\hline Chloride * (titrated) $(\mathrm{mg} / \mathrm{L})$ & $7 \pm 3$ & $14 \pm 2$ & 15 & 20 \\
\hline Ammonium $\mathrm{NH}_{4}-\mathrm{N}(\mathrm{mg} / \mathrm{L})$ & $0.15 \pm 0.07$ & $0.23 \pm 0.18$ & 34 & 41 \\
\hline \multicolumn{5}{|l|}{ Physico-chemical parameters } \\
\hline Electrical conductivity $(\mu \mathrm{S} / \mathrm{cm})$ & $156 \pm 17$ & $403 \pm 31$ & 15 & 38 \\
\hline $\mathrm{pH}$ & $7.8 \pm 0.3$ & $7.5 \pm 0.1$ & 23 & 43 \\
\hline Temperature $\left({ }^{\circ} \mathrm{C}\right)$ & $25.5 \pm 2.6$ & $24.8 \pm 1.1$ & 21 & 41 \\
\hline $\mathrm{ORP}[\mathrm{mV}]$ & ND & $476 \pm 58$ & ND & 38 \\
\hline Ultraviolet absorbance (UVA-254) $(1 / \mathrm{m})$ & $51.6 \pm 28.1$ & $0.8 \pm 0.9$ & 14 & \\
\hline Total organic carbon $(\mathrm{TOC})(\mathrm{mg} / \mathrm{L})$ & ND & $1.96 \pm 0.49 * *$ & ND & 16 \\
\hline
\end{tabular}

* titrated, ${ }^{* *}$ mix values, MPN-most propable number, ND-not determined.

\subsection{Turbidity}

Turbidity in the Ganga River averaged to $501 \pm 243$ NTU and was reduced to $0.55 \pm 0.63$ NTU in the bank filtrate (Figure 4), underlining the role of bank filtration as a barrier for particle ingress. The AFM filter further reduced the turbidity down to $0.30 \pm 0.34$ NTU, and by that substantially improved water quality prior to the chlorination. This value could be nearly maintained during the passage in the electrolysis cell but increased to $0.70 \pm 1.16 \mathrm{NTU}$ with outliers and $0.40 \pm 0.38 \mathrm{NTU}$ without outliers, which were caused by filter-breakthrough. The slight but constant increase of turbidity was traced back to calcareous deposits released from the electrolytic cell after polarity inversion. In the second short term trial, a second media filter was installed to remove those deposits.
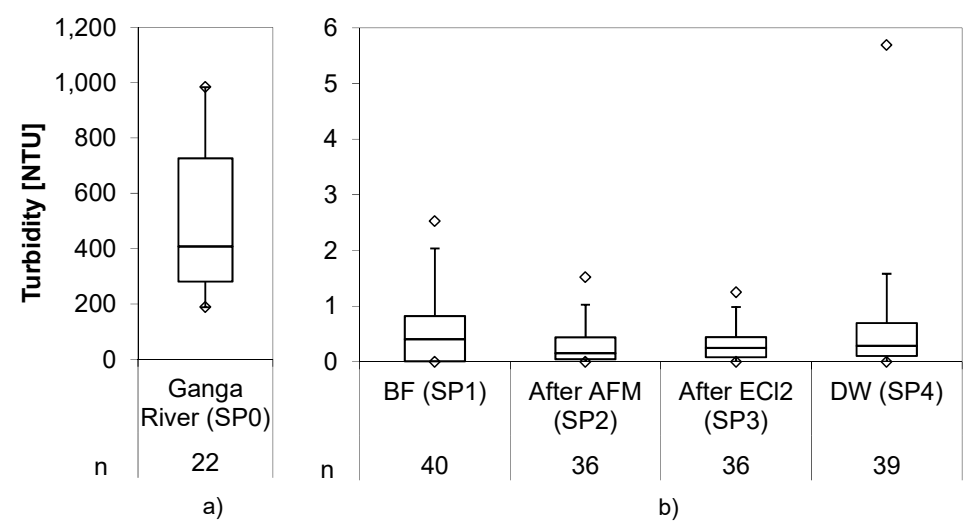

Figure 4. Turbidity values along water treatment.

\subsection{Disinfectant Production}

Figure 5 shows the ORP values of the bank filtrate and the final drinking water as well as the FAC and total chlorine in the drinking water storage tank.

The ORP increased from $476 \pm 58 \mathrm{mV}$ in the bank filtrate to $720 \pm 85 \mathrm{mV}$ in the drinking water tank. FAC and total chlorine values reached $0.27 \pm 0.17 \mathrm{mg} / \mathrm{L}$ and $0.30 \pm 0.16 \mathrm{mg} / \mathrm{L}$, respectively. Despite the fact that increased ORP values indicate the presence of chlorine, no direct correlation between both values could be drawn. As reasons for that, the slow reaction time of the ORP sensors in combination with a relatively small storage volume for the tested flow rates were identified. Whenever the ORP sensor indicated a low reading, the system automatically increased the chlorine production and reduced the flow rate. On the other hand, whenever the ORP sensor signaled a high reading, the system automatically decreased the chlorine production and increased the flow rate. Due to the small volume in the drinking water tank, an increase or decrease of chlorine concentration was not detected quickly enough by the ORP sensor. As a consequence, the chlorine concentration oscillated 
while the system tried to maintain the target ORP value. Because of this oscillation, the chlorine value fell from time-to-time below the minimum target value of $0.2 \mathrm{mg} / \mathrm{L}$ and reached high chlorine values of around $1 \mathrm{mg} / \mathrm{L}$. Disabling the automatic flow rate adaptation or using a larger drinking water storage tank would compensate for the delay of the ORP sensors in adjusting to changing chlorine levels, and thus could stabilize the chlorine concentration. The control mechanism was adapted in the second short term trial by removing the automatic adaptation of the flow rate, which proved to produce more constant results.
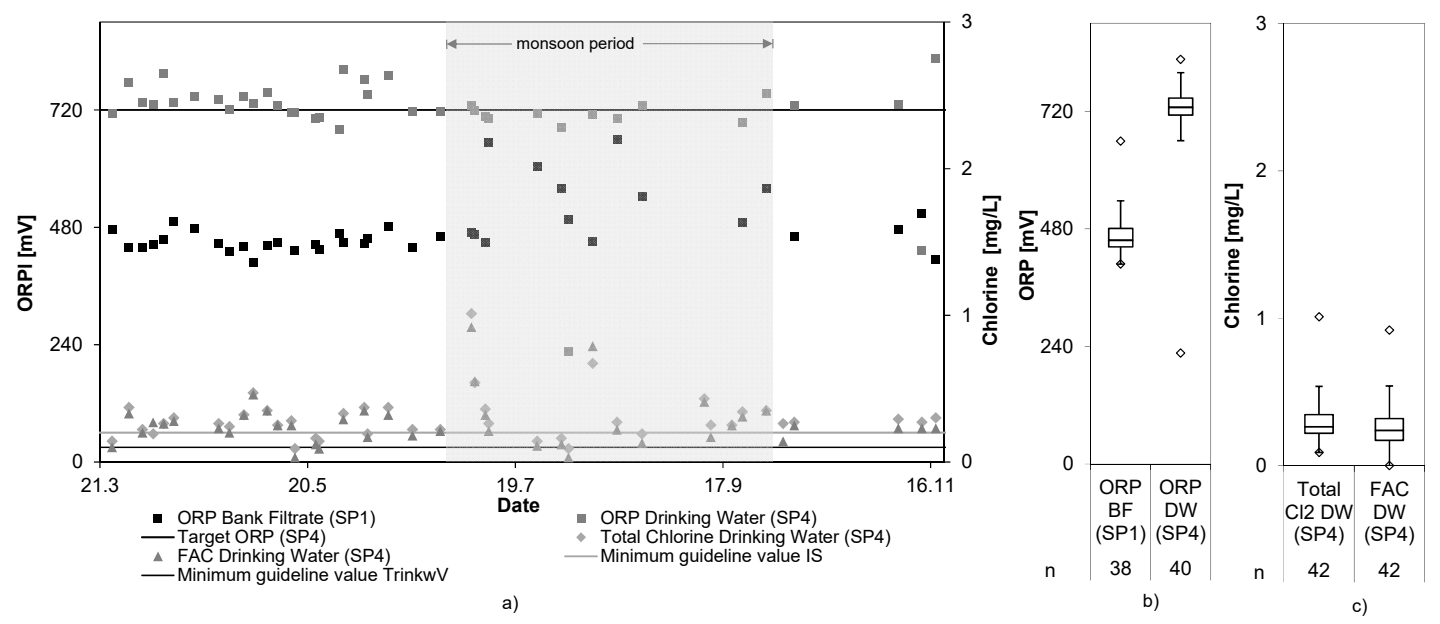

Figure 5. ORP of bank filtrate (SP1), $\mathrm{ECl}_{2}$ effluent (SP4), and chlorine (FAC and total) in $\mathrm{ECl}_{2}$ effluent (SP4) $(\mathbf{a}-\mathbf{c})$.

\subsection{Pathogens}

The analytical results of total coliforms and E. coli, as indicator pathogens, for the first trial period are shown in Figures 6 and 7.

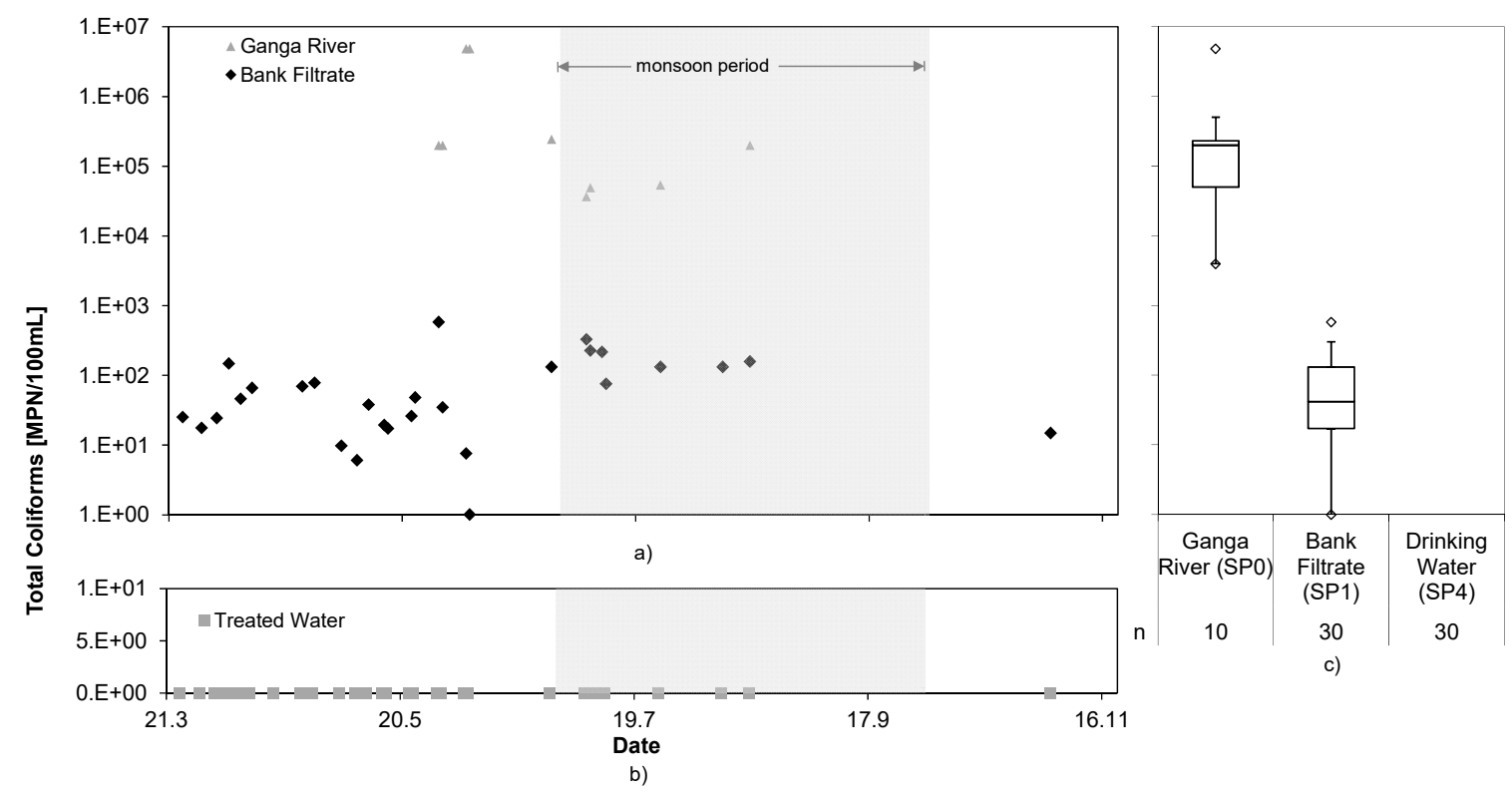

Figure 6. Total coliforms in the Ganga River water and bank filtrate (a) and drinking water (b), and statistical interpretation (c); trial period March-November. 


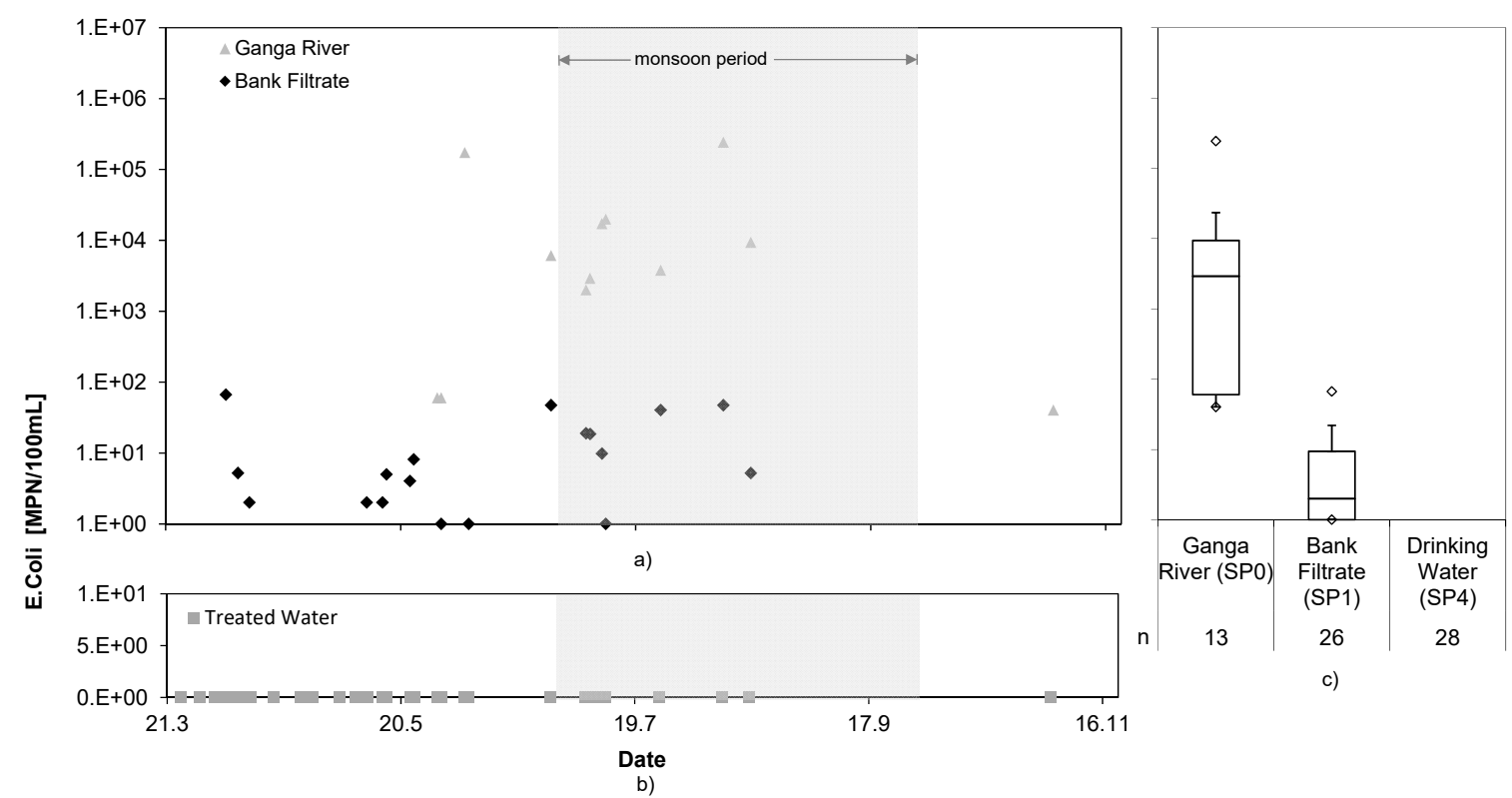

Figure 7. E. coli in the Ganga River water and bank filtrate (a) and drinking water (b), and statistical interpretation (c); trial period March-November.

The bank filtration achieved a $\log _{10}$ reduction of 3.9 and 3.6 for total coliforms and E. coli, respectively. It is assumed that the peak values in the bank filtrate did not originate from the Ganga River water, but rather came from seepage into the well from above, as described in [19]. However, the $\mathrm{ECl}_{2}$ system completely removed still present fecal indicators and water could be kept microbially safe at all times. The maximum log reduction of the $\mathrm{RBF}+\mathrm{ECl}_{2} \mathrm{cNES}$ achieved was $>6.7$ for total coliforms and $>5.4$ for E. coli. It can be assumed that even higher log reductions could be reached, considering presence of FAC in the treated water.

\subsection{Chlorine Demand}

During the trial period the chlorine demand $(\triangle \mathrm{FAC})$ was very low, with $0.03 \pm 0.03 \mathrm{mg} / \mathrm{L}$ on average, but peaked to $0.33 \mathrm{mg} / \mathrm{L}$. Combined chlorine, formed directly at SP3 and SP4, were $0.09 \pm 0.08 \mathrm{mg} / \mathrm{L}$ and $0.02 \pm 0.02 \mathrm{mg} / \mathrm{L}$, respectively (Figure 8 ).

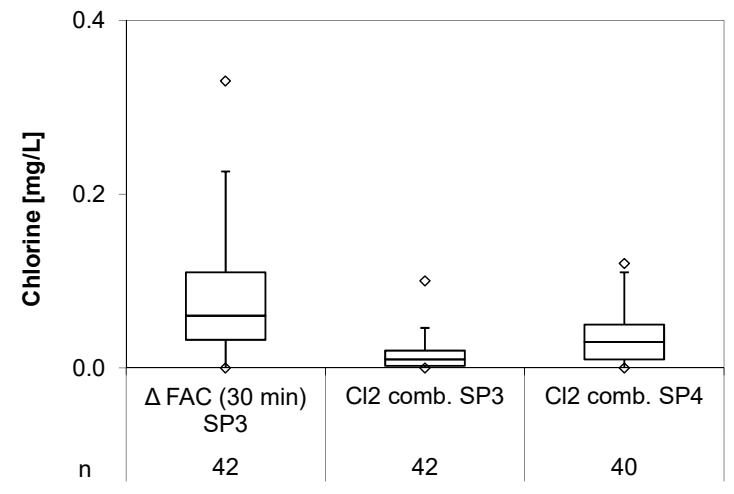

Figure 8. Combined chlorine formed at SP3 and SP4 as well as chlorine demand.

The low average values resulted from the low concentrations of ammonium and organics in the bank filtrate (see Table 4) and do not indicate any critical potential for organic disinfection by-product formation. However, as there are substantial fluctuations of organic and nitrogen compounds in the well water, an automated adaption of the chlorine production process is required to compensate for changing chlorine demand and combined chlorine formation. Even though there was no good 
correlation between ORP and chlorine concentration, the ORP can indicate insufficient supply of disinfectant and can; therefore, next to cell current and flow rate, be consideredas an additional parameter to control chlorine production.

\subsection{Electrical Conductivity and Chloride Concentration}

The correlation between electrical conductivity and chloride concentration is shown in Figure 9.

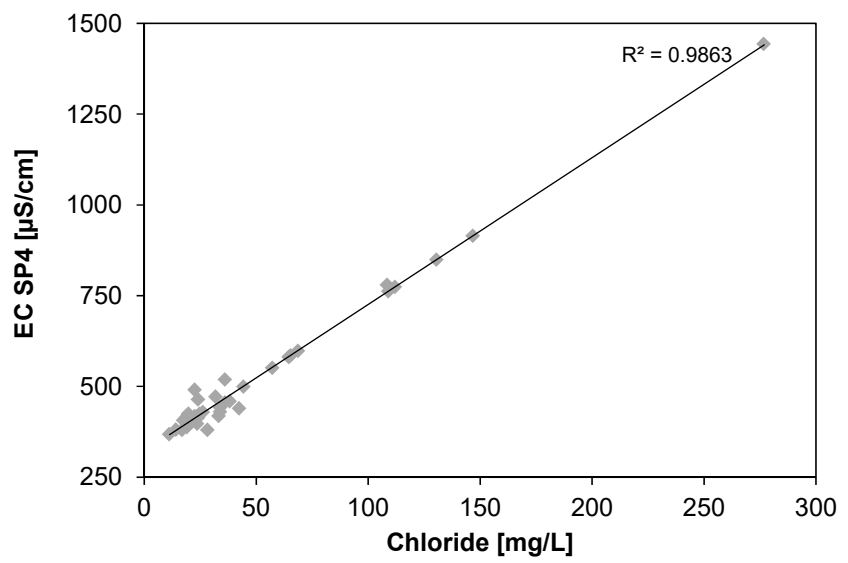

Figure 9. Correlation between conductivity and chloride concentration in treated water (SP4).

The scatterplot indicates that, especially at higher chloride concentrations, the effect of the chloride on the conductivity prevails towards other ions. In order to limit the $\mathrm{NaCl}$ consumption, the chloride concentration was supposed to be kept below $50 \mathrm{mg} / \mathrm{L}$. The incidents when higher concentrations occurred could be tracked back to either a nearly empty feed tank, into which the dosing pump dosed too much chloride for the water available, or to calcearous deposits that were formed on the cell. Those deposits have hampered the ability to reach a voltage/current ratio of $\leq 3$.

\subsection{Inorganic Disinfection By-Products}

The concentrations of the mixed samples for chloride and chlorate in SP3 (directly after the electrolysis cell) are shown in Figure 10.

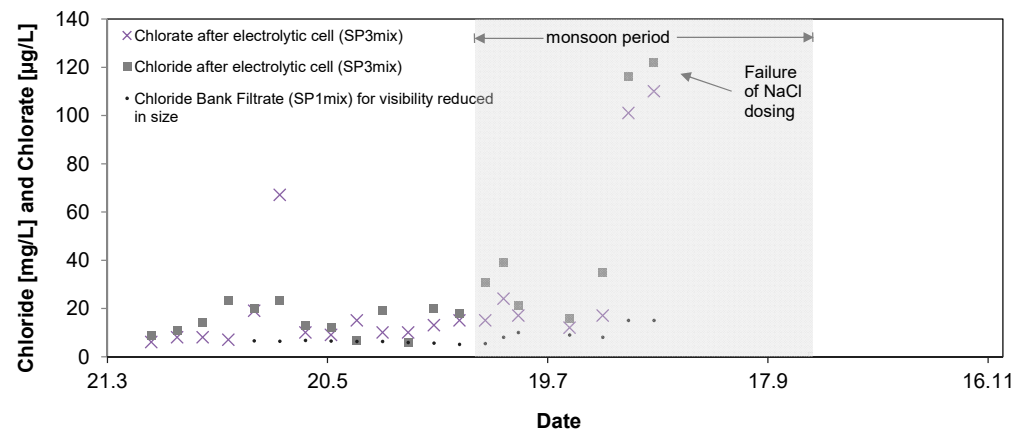

a)

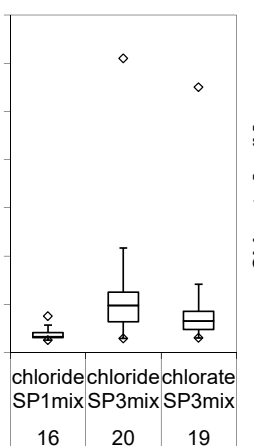

b)

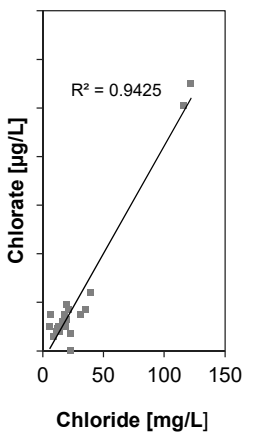

c)

Figure 10. Chloride and chlorate concentrations during field test (a,b), and their correlation (c).

Even after the long storage period of several weeks until analysis in Germany, the chlorate concentrations reached only $22 \pm 29 \mu \mathrm{g} / \mathrm{L}$ and is not of concern considering WHO and German guideline values (Table 1). Uncertainty towards the maximum chlorate values exists due to the mixing of two to three random samples into one sample per week, as the concentration of samples with higher concentration might have been lowered with samples of lower concentration. However, the correlation between chloride concentration and chlorate production (Figure 10c) show that 
higher chloride concentrations are required to reach elevated levels of chlorate. The two maximum chlorate concentrations above $100 \mu \mathrm{g} / \mathrm{L}$ went along with an excess of chloride added into the feed tank. Chlorite and perchlorate were always below the detection limit of $1 \mu \mathrm{g} / \mathrm{L}$ and are; therefore, not of concern when water is disinfected by means of inline-electrolysis with the here applied MOX-electrodes.

\subsection{Hardness}

Figure 11 shows the total hardness values measured during the first system trial.

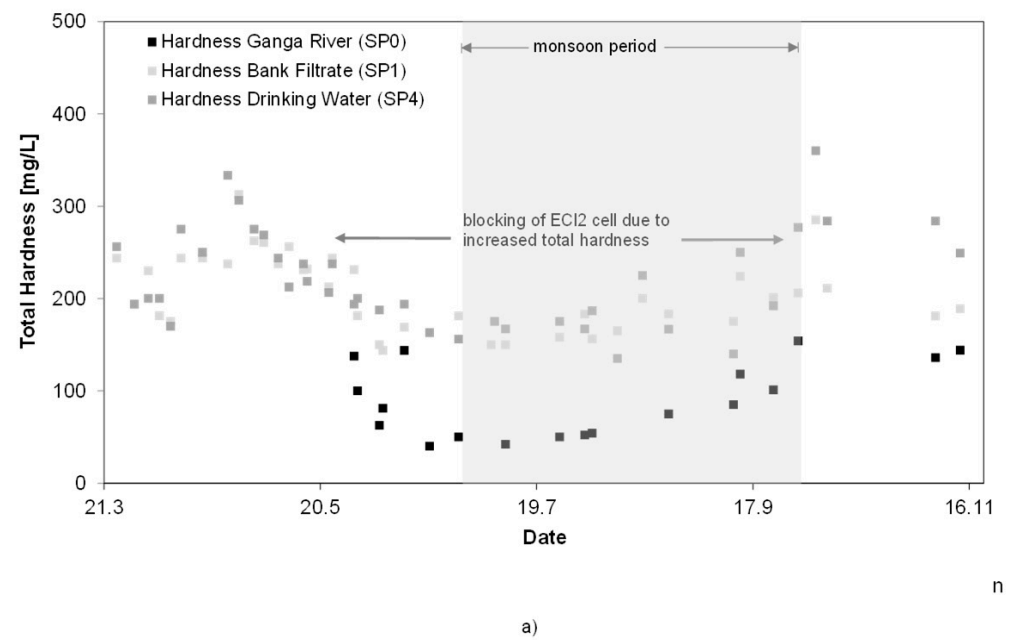

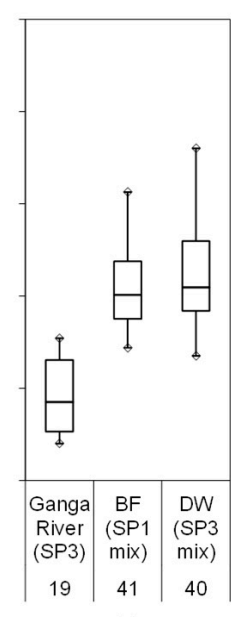

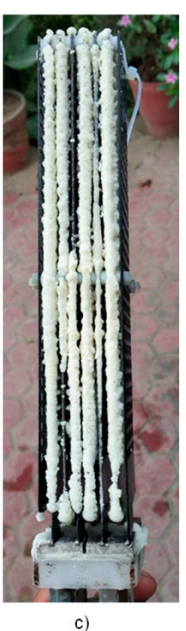

Figure 11. Total hardness values in SP0 and SP1 during the first long term test $(\mathbf{a}, \mathbf{b})$; and calcareous deposits on the $\mathrm{ECl}_{2}$-cell (c).

The hardness values were fluctuating throughout the test period in the Ganga River (92 $\pm 39 \mathrm{mg} / \mathrm{L})$ and the bank filtrate $(207 \pm 40 \mathrm{mg} / \mathrm{L})$. Whereas the values in the bank filtrate ranged around an unproblematic $200 \mathrm{mg} / \mathrm{L}$ during monsoon, the levels reached $\sim 300 \mathrm{mg} / \mathrm{L}$ before and after the monsoon season. Those values have shown to be problematic for system operation, as spontaneous growth of calcareous deposits on the $\mathrm{ECl}_{2}$ cell intermittently reduced chlorine production efficiency and required extra maintenance.

\subsection{Second Optimized Test Phase}

In the second short term test the automatic flow rate adaption was disabled and constant flow rates of 160,220, and $280 \mathrm{~L} / \mathrm{h}$ were established This was giving the ORP sensor sufficient time to detect changing chlorine concentrations and allowed the ability to test the system's reaction on changing chlorine demand in SP4, adjusting the cell current only. The main results of the second short term test are presented in Figure 12.

Despite the very short duration of this second pilot trial, it was sufficient to show that the fluctuation around the set target ORP of $700 \mathrm{mV}$ could be reduced to an acceptable level. The constant flow rates permitted an adequate utilization of the ORP reading for controlling the chlorine production and keeping the concentration in the desired range of $0.26 \pm 0.04 \mathrm{mg} / \mathrm{L}$. The presence of FAC in this concentration range was represented by elevated ORP values of $\sim 700 \mathrm{mV}$. It can be assumed that a larger drinking water storage tank (SP4) would have had a similar effect. Pathogens could still be completely removed through $\mathrm{ECl}_{2}$.

Further, the effect of the second AFM filter, placed behind the electrolytic cell to remove calcareous deposits, and the THM concentrations are shown in Figure 13b. 

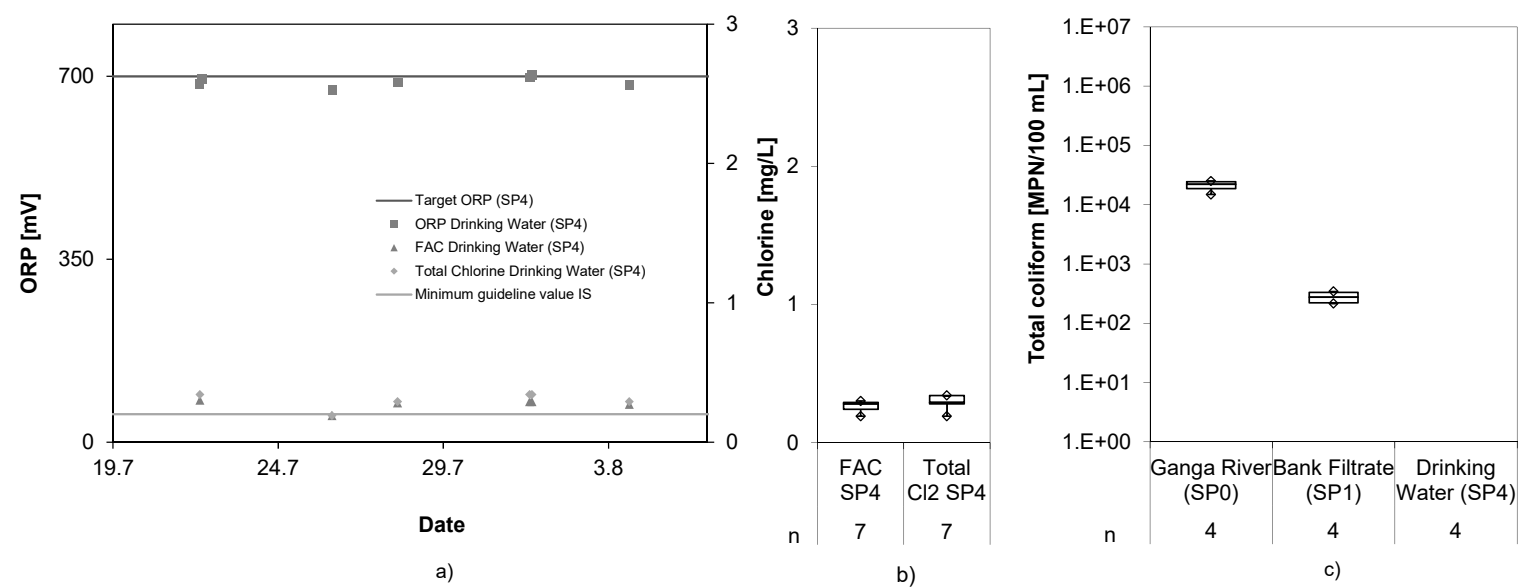

Figure 12. ORP and chlorine concentration in SP4 $(\mathbf{a}, \mathbf{b})$; and pathogenic contamination in short term test with optimized system setting $(\mathbf{c})$.

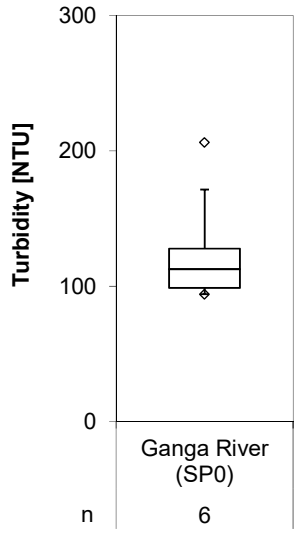

a)

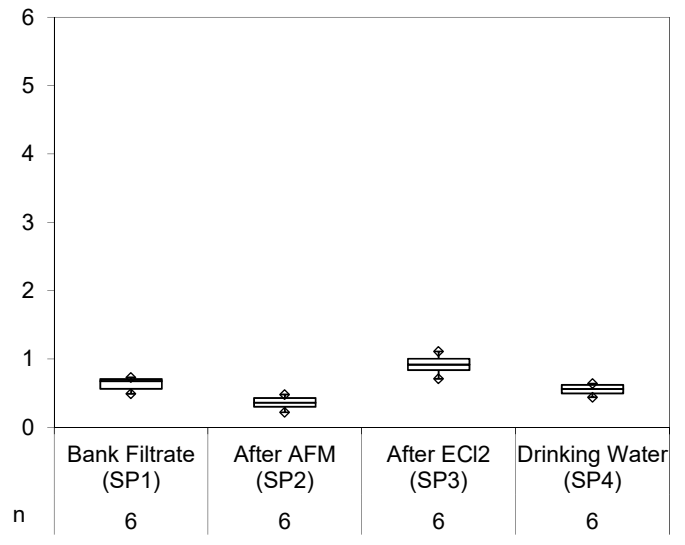

b)

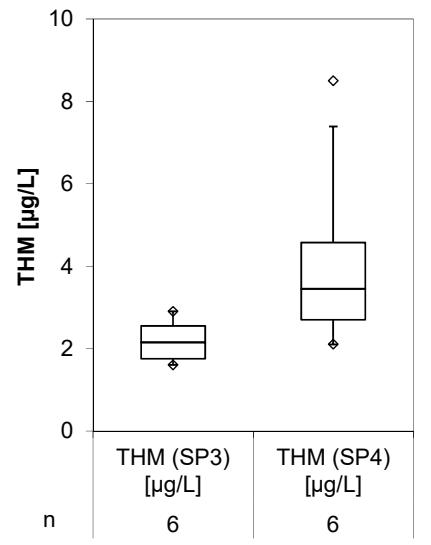

c)

Figure 13. Turbidity removal (a,b) and THM formation (c) during short term test with optimized system setting.

The second filter reduced the turbidity down to $0.55 \pm 0.08 \mathrm{NTU}$, after it had increased to $0.92 \pm 0.13$ NTU behind the electrolytic cell, improving overall water quality. The THM analysis showed concentrations of $2.2 \pm 0.5 \mu \mathrm{g} / \mathrm{L}$ in SP3 after $30 \mathrm{~min}$ and $4.2 \pm 2.1 \mu \mathrm{g} / \mathrm{L}$ in SP4. Those low concentrations were expected due to the low TOC and dissolved organic carbon DOC content of the water, allowing full compliance even with strict guideline values for DBPs (Table 1).

\subsection{Energy Demand and Solar Energy Supply}

During the first trial period a water volume of $1037 \mathrm{~m}^{3}$ was treated and the total electricity demand was summed up to $271 \mathrm{kWh}$ without and $412 \mathrm{kWh}$ with bank filtrate pumping. The average flow rate through the system, including off times (e.g., at night, during maintenance or repair) in Haridwar, was $180 \mathrm{~L} / \mathrm{h}$. This resulted in an average power demand of $46 \mathrm{~W}$ without and $70 \mathrm{~W}$ with bank filtrate pumping, and a per $\mathrm{m}^{3}$ energy consumption of $0.4 \mathrm{kWh}$ (Table 5).

Table 5. Energy demand of the tested $\mathrm{ECl}_{2}$ system.

\begin{tabular}{|c|c|c|c|c|c|c|}
\hline $\begin{array}{l}\text { Energy Demand } \\
\text { in }\left[\mathrm{kWh} / \mathrm{m}^{3}\right]\end{array}$ & $\begin{array}{c}\text { Water Pumping } \\
\text { through System incl. } \\
\text { AFM Filtration }\end{array}$ & $\begin{array}{c}\text { Inline } \\
\text { Electro- lysis }\end{array}$ & $\begin{array}{c}\text { Auxiliary and } \\
\text { Online Monitoring }\end{array}$ & $\begin{array}{c}\text { Total Demand } \\
\text { Water Treatment }\end{array}$ & $\begin{array}{c}\text { Pumping of Bank } \\
\text { Filtrate (BF) }\end{array}$ & $\begin{array}{l}\text { Total Demand } \\
\text { incl. Pumping }\end{array}$ \\
\hline $\begin{array}{l}\text { RBF AFM ECl } \\
\text { station in Haridwar }\end{array}$ & 0.06 & 0.19 & 0.02 & 0.26 & 0.14 & 0.40 \\
\hline
\end{tabular}


The power requirement of $70 \mathrm{~W}$ was used for the sensitivity analysis using different sized PV generators and different battery capacities considering the parameters mentioned in Table 3. The analysis shows that at least a 96 Ah battery system with minimum $800 \mathrm{Wp}$ are required to power the water treatment system for $22 \mathrm{~h}$ per day and a permitted capacity shortage of $1 \%$. The results are summarized in Table 6.

Table 6. Results of sensitive analysis based on shown PV battery combinations.

\begin{tabular}{|c|c|c|c|c|c|c|c|}
\hline $\begin{array}{l}\text { PV Generator Size and } \\
\text { Battery Capacity [W], [Ah] }\end{array}$ & $\begin{array}{l}\text { Total Prod. } \\
{[\mathrm{kWh} / \mathrm{a}]}\end{array}$ & $\begin{array}{l}\text { Total Cons. } \\
{[\mathrm{kWh} / \mathrm{a}]}\end{array}$ & $\begin{array}{l}\text { Input Battery } \\
{[\mathrm{kWh} / \mathrm{a}]}\end{array}$ & $\begin{array}{l}\text { Output Battery } \\
{[\mathrm{kWh} / \mathrm{a}]}\end{array}$ & $\begin{array}{l}\text { Excess Electricity } \\
{[\mathrm{kWh} / \mathrm{a}],[\%]}\end{array}$ & $\begin{array}{l}\text { Unmet Load } \\
{[\mathrm{kWh} / \mathrm{a}],[\%]}\end{array}$ & $\begin{array}{c}\text { Capacity Shortage } \\
{[\mathrm{kWh} / \mathrm{a}][\%]}\end{array}$ \\
\hline 600,144 & 928 & 560 & 343 & 285 & $310,33,4 \%$ & $1.90,0.3 \%$ & $2.13,0.4 \%$ \\
\hline 800,144 & 1237 & 561 & 335 & 279 & $619,50.3 \%$ & $0.80,0.1 \%$ & $0.89,0.2 \%$ \\
\hline $900,96^{*}$ & 1392 & 560 & 330 & 275 & $776,55.8 \%$ & $2.13,0.4 \%$ & $2.38,0.4 \%$ \\
\hline 900,144 & 1392 & 562 & 332 & 277 & $774,55.6 \%$ & $0.48,0.1 \%$ & $0.53,0.1 \%$ \\
\hline 1000,96 & 1546 & 561 & 339 & 274 & $930,60.2 \%$ & $1.58,0.2 \%$ & $1.78,0.3 \%$ \\
\hline
\end{tabular}

The simulation shows, that with the installed solar PV-battery combination of $900 \mathrm{Wp}$ and $2 \times 96 \mathrm{Ah}$, the required electricity can be supplied nearly throught the year. Only a few hours of electrictiy shortages including a 7-h long power cut in the middle of the monsoon in August occured. The total capacity shorage summed up to $0.4 \%$. Whether this is permissible in a real case scenario and whether this could be compensated by, for example, an increase of the water storage capacity depends on local conditions. The simulated power production and SoC is shown in Figure 14a,b, respectively.

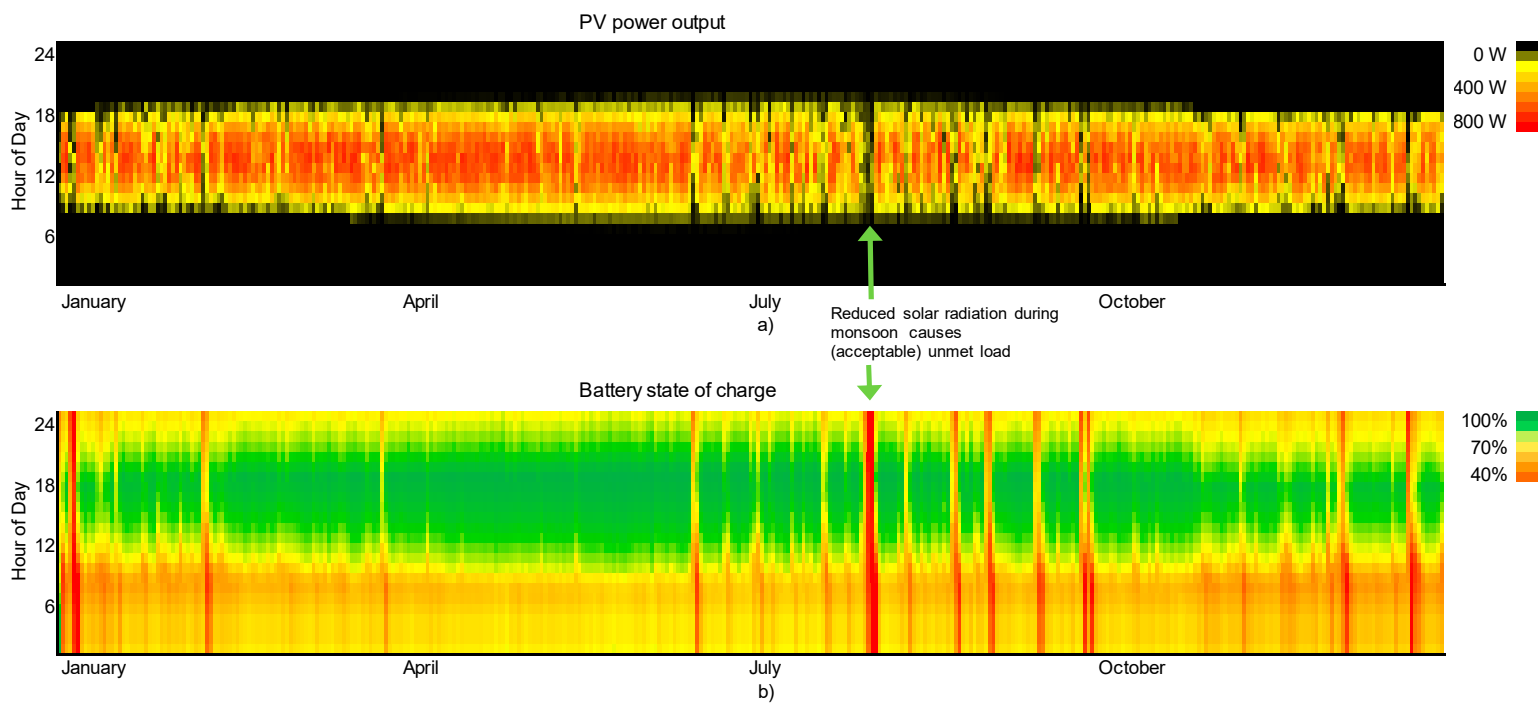

Figure 14. Power output from $900 \mathrm{Wp}$ PV panel (a) and corresponding State of Charge (SoC) (b).

During the trial the station was continuously running on the given solar PV system, as long as the modules were cleaned from dust frequently.

\section{Conclusions}

The presented results of a first long term and a second short term trial of a $\mathrm{RBF} \mathrm{ECl}_{2} \mathrm{combination}$ in India show that the tested system poses a feasible alternative for decentralized and safe drinking water supply for river bound communities in developing countries. RBF serves as a very efficient pre-treatment step, substantially reducing pathogens, turbidity, and DBP precursors. The installed AFM filter is capable of further reducing the already low turbidity values and the $\mathrm{ECl}_{2}$ system completely removes all still-present indicator pathogens, and supplies sufficient residual disinfectant for safe water distribution. The station complies with given water regulations concerning indicator 
pathogen and chlorine concentrations. Additionally, the production of DBPs is of no concern and stays well below the given guideline values. The first test period revealed some optimization potential of the control algorithm and the system setting, which was successfully implemented for the second trial. After that, the system reacted reliably to changing source water and operating conditions by keeping the residual disinfectant at a constant level. The used ORP sensor is able to indicate "sufficient" or "insufficient" disinfectant once it is given sufficient reaction time. For more accurate and faster readings, the application of chlorine probes may be an alternative to ORP probes.

Clogging of the electrolytic cell, due to increased levels of hardness, remains an operational challenge of the $\mathrm{ECl}_{2}$, which needs to be specifically addressed. With polarity inversion alone, and total hardness levels above $200 \mathrm{mg} / \mathrm{L}$, the operation of an $\mathrm{ECl}_{2}$ system currently reduces the maintenance intervals to about once every two months. The operation of the $\mathrm{ECl}_{2}$ system at total hardness values above $300 \mathrm{mg} / \mathrm{L}$ is currently not advisable. With the implementation of an additional probe to measure electrical conductivity, cell overgrowth could be detected by monitoring current and voltage of the cell and comparing them with the actual conductivity of the water.

After this trial, the system is mature enough to be implemented in a real scenario and under favorable operational conditions and source water quality, and it should be possible to reduce the maintenance intervals of the station to six months. For this, the implemented SCADA system will play an important role. An increase of the treatment capacity is straight forward by increasing the $\mathrm{ECl}_{2}$-cell size and the solar energy supply accordingly.

Author Contributions: P.O., A.G., and F.B. developed the pilot station; P.O. reviewed the literature, analyzed the data, and prepared the draft of the publication; F.B. dimensioned the solar energy supply system; P.M., S.K.S., and P.C.K. took care of the infrastructure for the pilot study; P.M., G.N., and M.W. analyzed water samples and contributed expertise in interpreting results; and C.S. and T.G. supported the planning and design of the experiments and the preparation of the draft. All co-authors reviewed and edited the draft.

Funding: All primary data was collected within the AquaNES project. This project has received funding from the European Union's Horizon 2020 Research and Innovation Program, under grant no. 689450

Acknowledgments: This study was based on the excellent support from Uttarakhand Jal Sansthan (UJS), which provided the pilot locations and supported in-system construction and operation, and the work performed by many staff members of UJS. The authors also gratefully acknowledge support from S. Hertel, for supporting literature review, and from F. Kowalczyk, F. Bauer, R. Rajoriya, F. Naumann, Binod Das, and P. Patwal during sampling, water analysis, and system maintenance.

Conflicts of Interest: The authors declare no conflict of interest.

\section{References}

1. Onda, K.; LoBuglio, J.; Bartram, J. Global access to safe water: Accounting for water quality and the resulting impact on MDG progress. Int. J. Environ. Res. Public Health 2012, 9, 880-894. [CrossRef] [PubMed]

2. Bain, R.; Cronk, R.; Hossain, R.; Bonjour, S.; Onda, K.; Wright, J.; Yang, H.; Slaymaker, T.; Hunter, P.; Prüss-Ustün, A.; et al. Global assessment of exposure to faecal contamination through drinking water based on a systematic review. Trop. Med. Int. Health 2014, 19, 917-927. [CrossRef] [PubMed]

3. Bain, R.; Cronk, R.; Wright, J.; Yang, H.; Slaymaker, T.; Bartram, J. Fecal contamination of drinking-water in low- and middle-income countries: A systematic review and meta-analysis. PLoS Med. 2014, 11, e1001644. [CrossRef] [PubMed]

4. World Health Organization (WHO). Drinking Water Key Facts. 2018. Available online: http:/ / www.who. int/en/news-room/fact-sheets / detail/drinking-water (accessed on 2 October 2018).

5. Hossain, M.A.; Sengupta, M.K.; Ahamed, S.; Rahman, M.M.; Mondal, D.; Lodh, D.; Das, B.; Nayak, B.; Roy, B.K.; Mukherjee, A.; et al. Ineffectiveness and Poor Reliability of Arsenic Removal Plants in West Bengal, India. Environ. Sci. Technol. 2005, 39, 4300-4306. [CrossRef] [PubMed]

6. Sobsey, M.D.; Handzel, T.; Venczel, L. Chlorination and safe storage of household drinking water in developing countries to reduce waterborne disease. Water Sci. Technol. A J. Int. Assoc. Water Pollut. Res. 2003, 47, 221-228. [CrossRef]

7. Montgomery, M.A.; Elimelech, M. Water and Sanitation in Developing Countries: Including Health in the Equation. Environ. Sci. Technol. 2007, 41, 17-24. [CrossRef] [PubMed] 
8. Roberts, L.; Chartier, Y.; Chartier, O.; Malenga, G.; Toole, M.; Rodka, H. Keeping clean water clean in a Malawi refugee camp: A randomized intervention trial. Bull. World Health Organ. 2001, 79, $280-287$. [PubMed]

9. Lorenzen, G.; Sprenger, C.; Taute, T.; Pekdeger, A.; Mittal, A.; Massmann, G. Assessment of the potential for bank filtration in a water-stressed megacity (Delhi, India). Environ. Earth Sci. 2010, 61, 1419-1434. [CrossRef]

10. Dash, R.R.; Bhanu Prakash, E.V.P.; Kumar, P.; Mehrotra, I.; Sandhu, C.; Grischek, T. River bank filtration in Haridwar, India: Removal of turbidity, organics and bacteria. Hydrogeol. J. 2010, 18, 973-983. [CrossRef]

11. Weiss, W.J.; Bouwer, E.J.; Aboytes, R.; LeChevallier, M.W.; O'Melia, C.R.; Le, B.T.; Schwab, K.J. Riverbank filtration for control of microorganisms: Results from field monitoring. Water Res. 2005, 39, 1990-2001. [CrossRef]

12. Sandhu, C.; Grischek, T.; Kumar, P.; Ray, C. Potential for Riverbank filtration in India. Clean Technol. Environ. Policy 2011, 13, 295-316. [CrossRef]

13. Wang, J.; Smith, J.; Dooley, L. (Eds.) Evaluation of Riverbank Infiltration as a Process for Removing Particles and DBP Precursors; American Water Works Association: Denver, CO, USA, 1996.

14. Grischek, T.; Paufler, S. Prediction of Iron Release during Riverbank Filtration. Water 2017, 9, 317. [CrossRef]

15. Sandhu, C.; Grischek, T. Riverbank filtration in India-Using ecosystem services to safeguard human health. Water Sci. Technol. Water Supply 2012, 12, 783-790. [CrossRef]

16. Wintgens, T.; Nattorp, A.; Elango, L.; Asolekar, S.R. Natural Water Treatment Systems for Safe and Sustainable Water Supply in the Indian Context: Saph Pani. Water Intell. Online 2016, 15, 9781780408392. [CrossRef]

17. Ghodeif, K.; Grischek, T.; Bartak, R.; Wahaab, R.; Herlitzius, J. Potential of river bank filtration (RBF) in Egypt. Environ. Earth Sci. 2016, 75, 255. [CrossRef]

18. Pholkern, K.; Srisuk, K.; Grischek, T.; Soares, M.; Schäfer, S.; Archwichai, L.; Saraphirom, P.; Pavelic, P.; Wirojanagud, W. Riverbed clogging experiments at potential river bank filtration sites along the Ping River, Chiang Mai, Thailand. Environ. Earth Sci. 2015, 73, 7699-7709. [CrossRef]

19. Bartak, R.; Page, D.; Sandhu, C.; Grischek, T.; Saini, B.; Mehrotra, I.; Jain, C.K.; Ghosh, N.C. Application of risk-based assessment and management to riverbank filtration sites in India. J. Water Health 2015, 13, 174-189. [CrossRef] [PubMed]

20. Hashmi, I.; Farooq, S.; Qaiser, S. Chlorination and water quality monitoring within a public drinking water supply in Rawalpindi Cantt (Westridge and Tench) area, Pakistan. Environ. Monit. Assess. 2009, 158, 393-403. [CrossRef] [PubMed]

21. Clasen, T.; Haller, L.; Walker, D.; Bartram, J.; Cairncross, S. Cost-effectiveness of water quality interventions for preventing diarrhoeal disease in developing countries. J. Water Health 2007, 5, 599-608. [CrossRef] [PubMed]

22. Morris, R.D.; Audet, A.M.; Angelillo, I.F.; Chalmers, T.C.; Mosteller, F. Chlorination, chlorination by-products, and cancer: A meta-analysis. Am. J. Public Health 1992, 82, 955-963. [CrossRef]

23. World Health Organization (WHO). Guidelines for Drinking-Water Quality; World Health Organization: Geneva, Switzerland, 2017.

24. Kraft, A. Electrochemical Water Disinfection: A Short Review. Platin. Met. Rev. 2008, 52, 177-185. [CrossRef]

25. European Commission. Proposal for a Directive of the European Parliament and of the Council on the Quality of Water Intended for Human Consumption (Recast); European Commission: Brussels, Belgium, 2018.

26. Otter, P. Experimental Determination of the Optimization Potential of an Energy Autarkic Drinking Water Purification System Under the Consideration of Local Conditions in the Rubber Trapper Reserve "RESEX do Rio Ouro Preto" Located in the Brazilian State of Rondônia. Master's Thesis, University of Kassel, Kassel, Germany, 2010.

27. Kraft, A.; Blaschke, M.; Kreysig, D.; Sandt, B.; Schröder, F.; Rennau, J. Electrochemical water disinfection. Part II: Hypochlorite production from potable water, chlorine consumption and the problem of calcareous deposits. J. Appl. Electrochem. 1999, 29, 895-902. [CrossRef]

28. Schmidt, W. Untersuchungen zur Desinfektionswirkung und Sicherheit der In-line-Elektrolyse von Chlor als umweltschonendes Verfahren für die Desinfektion von Trinkwasser-In-line-Elektrolyse für die Trinkwasserdesinfektion (Investigations on the Disinfecting Effectiviness and Safety of the In-Line Electrolysis of Chlorine as an Environmentally Friendly Process for the Disinfection of Drinking Water In-Line Electrolysis for Drinking Water Disinfection); DBU Report; Deutsche Bundesstiftung Umwelt: Osnabrück, Germany, 2012. 
29. Haaken, D.; Dittmar, T.; Schmalz, V.; Worch, E. Influence of operating conditions and wastewater-specific parameters on the electrochemical bulk disinfection of biologically treated sewage at boron-doped diamond (BDD) electrodes. Desalin. Water Treat. 2012, 46, 160-167. [CrossRef]

30. Kraft, A.; Stadelmann, M.; Blaschke, M.; Kreysig, D.; Sandt, B.; Schröder, F.; Rennau, J. Electrochemical water disinfection Part I: Hypochlorite production from very dilute chloride solutions. J. Appl. Electrochem. 1999, 29, 859-866. [CrossRef]

31. Deutscher Verein des Gas und Wasserfaches. DVGW W 296 (A): Trihalogenmethanbildung-Vermindern, Vermeiden und Ermittlung des Bildungspotentials (Trihalogenmethane Formation-Reduction, Avoidance and Determination of Formation Potential); Wirtschafts- und Verlagsgesellschaft Gas und Wasser mbH: Bonn, Germany, 2014.

32. Lilienthal, P.; Lambert, T.; Gilman, P. Homer: The Micropower Optimization Model; Homer Energy, LLC.: Boulder, CO, USA, 2009.

(C) 2019 by the authors. Licensee MDPI, Basel, Switzerland. This article is an open access article distributed under the terms and conditions of the Creative Commons Attribution (CC BY) license (http:/ / creativecommons.org/licenses/by/4.0/). 